\title{
Nutrition-related aspects of ascites in poultry
}

\author{
Vladimir Dosković ${ }^{1}$, Snežana Bogosavljević-Bošković ${ }^{1}, Z_{\text {Zdenka Škrbić }}$, \\ Miloš Lukić2 ${ }^{2}$, Božidar Milošević, ${ }^{3}$, Simeon Rakonjac ${ }^{1}$, Veselin Petričević ${ }^{2}$ \\ ${ }^{1}$ Faculty of Agronomy, Čacak, University of Kragujevac, Serbia \\ ${ }^{2}$ Institute for Animal Husbandry, Belgrade-Zemun, Serbia \\ ${ }^{3}$ Faculty of Agriculture, University of Priština, Kosovska Mitrovica-Zubin Potok- \\ Lešak \\ Corresponding author: vladosko@kg.ac.rs
}

\begin{abstract}
Pulmonary hypertension syndrome or ascites is a complex problem in poultry production. This disease has multiple causes, including genetic factors (genotype, sex) and non-genetic factors (altitude, improper egg incubation, ambient conditions in the poultry house, diet, etc.). Results from numerous studies have shown that improper diet and its interaction with other factors are among major reasons for the incidence of ascites symptoms. The objective of this study was to highlight major nutritional aspects related to pulmonary hypertension syndrome in broiler chickens. Therefore, particular attention should be paid to the dietary levels of antioxidant compounds, some minerals, energy and protein, feed forms, type of diet, and feed supplementation with ingredients which reduce the incidence of ascites.
\end{abstract}

Keywords: poultry, ascites syndrome, diet.

\section{Introduction}

Over the last half century, intensive selection work in broiler production has led to great changes in broiler production parameters (daily weight gain, feed consumption, feed conversion ratio), as well as in the quantitative and qualitative characteristics of dressed carcasses. 
Heavy strains of broilers produced today are characterised by intensive rapid growth, low mortality rates, low feed intake per unit of weight gain, excellent adaptability to intensive production conditions, good resistance and vitality, rapid feathering, white feathers, strong physique, long wide breast muscles and short leg muscles, good body conformation, intensive basal metabolism, increased meat yield - dressing percentage, increased proportion of breasts, and distinct skin pigmentation.

Modern broiler strains have huge problems associated with all nutritional ingredients - energy, protein, amino acids, macro- and microelements, and vitamins.

Selection for rapid growth in broilers primarily requires the use of feeds rich in nutrients, principally energy and protein, and intensive feed consumption. This leads to increased rates of nutrient digestion and metabolism, and hence a greater cardiovascular and respiratory load. The intensification of metabolism demands a large amount of oxygen. However, as the cardiopulmonary system is unable to keep up with the increased oxygen demand, lack of oxygen i.e. hypoxia and pulmonary hypertension occur in the body. All these disorders consequently lead to ascites or pulmonary hypertension syndrome (PHS). This disease is also called "water belly". As it seems, lung volume in broilers has reached its limit to the blood flow that can be accommodated; therefore, further improvement in growth rate will require increasing the capacity of both the lungs and the abdominal cavity (Julian, 1993).

Ascites is a widespread, highly complex problem in poultry production. It is estimated that the annual damage from this disease worldwide is about 1 billion $\$$ (Maxwell and Robertson, 1997), and that about 5\% of broilers and $20 \%$ of roaster chickens die of ascites (Balog, 2003).

Chickens with ascites have distended abdomens, respiratory distress and cyanosis. Breast muscles turn dark, and up to $300 \mathrm{ml}$ of clear yellow fluid with clots of fibrin is pooled in the distended abdominal cavity. The right half of the heart is enlarged, dilated and hypertrophic. The liver is grey and enlarged. The lungs are oedematous. At slaughter, carcasses of these chickens are discarded as unusable (Maslić-Strižak et al., 2012). Ascites is the accumulation of excess lymph in the peritoneal space (Julian, 1993). As lung capacity in ascites does not increase in proportion to body mass, this disorder leads to hypoxia, hypercapnia and respiratory acidosis (Surai, 2000).

Ascites is induced by multiple (genetic and non-genetic) factors, and not by a single factor, but generally by a combination of factors.

\section{Ascites}

\section{Egg incubation}

Improper egg incubation, accompanied by problems such as high or low temperature in the incubator and variable concentrations of $\mathrm{O}_{2}$ and $\mathrm{CO}_{2}$ during 
incubation, is a potential cause of ascites in chickens (Julian, 2000; Franciosini et al., 2012).

\section{Ambient conditions}

Poor ambient conditions in the chicken house, including low temperatures and the associated stress (Balog et al., 2003) and temperature fluctuations, cause ascites. In their study on growth, carcass characteristics, and incidence of ascites in broilers exposed to environmental fluctuations and oiled litter, McGovern et al. (2000) determined that the rate of ascites-induced mortality was higher $(6.3 \%)$ in chickens exposed to temperature fluctuations than in those exposed to control temperature (4.6\%), but no significance was observed. Also, Bendheim et al. (1992) found the highest rate of ascites-induced mortality in birds fed pelleted feed and exposed to cold temperatures, and the lowest in broilers receiving mash feed under controlled (warm) temperature conditions. Therefore, as highlighted by Groves (1997) and Aftab and Khan (2005), maintaining optimal temperature and ventilation in the poultry house is a very important factor in ascites prevention.

\section{Stocking densities}

Increased stocking densities contribute to the pulmonary hypertension syndrome, not only due to inadequate oxygen supply, but also due to injuries (Martrenchar et al., 1997; Scheele et al., 2005).

\section{Short daylight periods}

Short daylight periods, particularly in fast-growing hybrids, can induce pulmonary hypertension syndrome. Shortening daylight periods at 3 to 4 days of age can reduce the incidence of ascites by 30 to $60 \%$, as related with the reduced rate of growth during the first week of life; and providing broilers with 23 hours of light until day 35 results in satisfactory production performance (Decuypere et al., 2000). Mortality due to ascites is reduced in broilers subjected to restricted lighting programmes compared to non-restricted birds (Hassanzadeh et al., 2003).

\section{Altitude}

Ascites is also caused by altitude at which chicken facilities are located (Julian, 1998). At every thousand metres of altitude, the partial pressure of oxygen decreases by about $7 \mathrm{~mm}$ of the mercury column (resulting in reduced oxygen availability in the lungs) (Druyan, 2012). Due to the reduced concentration of oxygen at high altitudes, chicken houses should not be built at all in regions above 1800m (Maslić-Strižak et al., 2012). 


\section{Genotype}

Genotype of broiler chickens is another factor in the occurrence of ascites syndromes as the rate of broiler growth directly induces the pulmonary hypertension syndrome (Camacho et al., 2004). Haemoglobin saturation is lower in fast-growing broilers than in slow-growing birds (Mirsalimi, 1992; Al-Mesri and Hassanzadeh, 2010). As it seems, lung volume in broilers has reached its limit to the blood flow that can be accommodated; therefore, further improvement in growth rate will require increasing the capacity of both the lungs and the abdominal cavity (Julian, 1993).

\section{Broiler sex}

Broiler sex also causes ascites, which is more likely to occur in male broilers than in females (Julian et al., 1986; Bendheim et al., 1992; Camacho-Fernandez et al., 2002). Separate sex feeding has been recommended (Curie, 1999).

\section{Diseases}

The fungus Aspergillus fumigatus, the causal agent of Aspergillosis, causes severe cases of ascites due to its negative effect on respiratory tissues (Julian and Boulianne, 1988; Julian, 1993).

\section{Toxins in feed}

Feed must be microbiologically safe, with no presence of toxins (Gupta et al., 2011). Ascites in broilers is caused by hepatotoxin and high amounts of furazolidone in feed (Bhagat et al., 1990), as well as by mycotoxins (Issac et al., 2010).

\section{Feed ingredients}

The presence of antioxidant compounds (vitamins A, E, C, glutathione, uric acid, cysteine, glucose, enzymes: superoxide dismutase, catalase, glutathione reductase and glutathione peroxidase) in the circulation or at the level of the respiratory membrane may lessen cellular damage, prevent the induction of hypoxia, and thus reduce the incidence of ascites (Currie, 1999).

Dietary supplementation with vitamin $\mathrm{C}$, vitamin $\mathrm{E}$ and selenium can decrease the rate of mortality, as they are effective in reducing the generation of free radicals related to ascites (Hassanzadeh et al., 1997; Issac et al., 2010).

When used in the diet of broiler chickens, tocopherol (Villar-Patino et al., 2002) improves body antioxidant status, thus preventing the incidence of ascites. As disturbance in cellular antioxidant status contributes to ascites, dietary supplementation with high concentrations of vitamin $\mathrm{E}$ has been recommended as a means of decreasing the level of oxidative stress in lung blood, given the low tocopherol concentrations in the liver and lungs of broilers affected by the pulmonary hypertension syndrome (Maslić-Strižak et al., 2012). 
When evaluating the effect of low ambient temperature on growth performance, ascites-related traits, antioxidant enzyme activities, and serum Troponin-T levels in male broiler chicks (Ross), as well as the effect of dietary vitamin E supplementation on ascites syndrome, Akşit et al. (2008) found no improvement in performance, molecular parameters of oxidative stress and myocardial damage after dietary supplementation with $200 \mathrm{mg} / \mathrm{kg}$ Vitamin E, regardless of some reduction in the rate of mortality due to ascites. However, this finding does not rule out the potentially beneficial effect of vitamin $\mathrm{E}$ supplementation in reducing ascites-related damage.

Basmacioğlu Malayoğlu et al. (2009) examined the effect of dietary vitamin E ( $\alpha$-tocopheryl acetate) and organic selenium supplementation on the performance and antioxidant status of Hubbard-JV broilers fed n-3 PUFAenriched feeds, and determined that $1.5 \%$ fish oil may not cause significant oxidative stress in broilers.

In Cobb 500 male broilers receiving ad libitum water and a diet $(23.7 \%$ protein; $3.200 \mathrm{kcal} \mathrm{ME}$ ) supplemented with 15 (normal) or $100 \mathrm{IU} \mathrm{dl}-\alpha$ tocopherol acetate (vitamin E) per $\mathrm{kg}$, Iqbal et al. (2002) analysed fatty acid profile and activities of enzymatic antioxidants in pulmonary mitochondria and liver tissue associated with ascites and a high vitamin E supply, and suggested that high dietary levels of vitamin E reduced the levels of unsaturated fatty acids in lung mitochondria, thus increasing their resistance to lipid peroxidation and oxidative stress, and alleviating the oxidative stress caused by pulmonary hypertension syndrome.

Lin et al. (2005) found that maternal supplementation with high levels of vitamin E (120-160 mg/kg) in corn-soybean growing diets enhances antioxidant capability and depresses oxidative stress in chicks.

Optimal supply of broiler feeds with vitamin $\mathrm{C}$ as both an antistress factor and an antioxidant has also been recommended; moreover, vitamin $\mathrm{C}$ exhibits metabolic activity as it reduces resistance to blood flow through narrow capillaries of the lungs (Decuypere et al., 2005).

Vitamin $\mathrm{C}$ reduces the incidence of ascites and the associated pulmonary arteriolar muscularisation caused by cool environmental temperatures and dietary $\mathrm{T}_{3}$ (thyroid hormone) supplementation (Xiang et al., 2002). Also, Hassanzadeh et al. (1997) reported that vitamin C supplementation at $500 \mathrm{mg} / \mathrm{kg}$ feed in Ross male broilers significantly decreased mortality due to ascites, which was attributable to low ambient temperatures or diets supplemented with $\mathrm{T}_{3}$, with no concomitant effect on broiler performance. Moreover, vitamin C significantly decreased plasma thyroid hormone levels.

In their research on the effects of dietary supplementation with vitamin $\mathrm{C}$ or vitamin $\mathrm{E}$ on cardiac lipid peroxidation and growth performance in Arbor Acres broilers at risk of developing ascites syndrome, Villar-Patino et al. (2002) determined better performance (growth rate, feed consumption, feed conversion) in broilers receiving vitamin $\mathrm{C}$ (400 $\mathrm{mg}$ of ascorbic acid/kg of feed) or vitamin $\mathrm{E}$ 
(75 mg of DL- $\alpha$-tocopherol acetate/kg of feed) than in control birds, but found no difference in overall mortality and ascites-induced mortality as the result of feeding treatments. The same authors recommended limited levels of vitamin $\mathrm{E}$ in diets for older broilers (4 to 7 weeks of age) to reduce feed costs.

Ruiz-Feria (2009) studied whether supplementation of the basal diet with arginine (1\% supplemental l-arginine monohydrochloride), vitamin E (200 IU of vitamin E per kilogram of feed) and vitamin C $(500 \mathrm{mg} / \mathrm{kg}$ of vitamin C per kilogram of feed), used separately or in combination, improved cardiopulmonary performance in Cobb 500 broiler chickens, and found that cardiopulmonary performance improved and pulmonary hypertension reduced as the result of the additive effect of concurrent supplementation with vitamins $\mathrm{E}$ and $\mathrm{C}$, and the associated oxidative stress reduction. For the same hybrid of broilers (Cobb 500) exposed to subnormal temperatures, Lorenzoni and Ruiz-Feria (2006) observed that arginine $(0.3 \%$, provided with water) improved pulmonary arterial relaxation, when used separately, and decreased pulmonary vasodilation performance, when combined with vitamin $\mathrm{C}$.

Tan et al. (2005) reported that, under cool ambient temperature conditions, mortality attributable to pulmonary hypertension syndrome was lower in broilers fed a maize- and soybean meal-based diet supplemented with L-arginine (1\%) than in birds receiving no supplementation of this amino acid.

Arginine improved pulmonary vascular performance in broiler chickens reared under hypoxia, and even more so when combined with the antioxidant vitamins $\mathrm{E}$ and $\mathrm{C}$. This suggests potential complementary or synergistic interactions between arginine and the antioxidant vitamins in reducing oxidative stress-related damage and, hence, improving cardiopulmonary performance (Bautista-Ortega and Ruiz-Feria, 2010).

Feed supplementation with flaxseed oil at $50 \mathrm{~g} / \mathrm{kg}$ feed reduced, although non-significantly, the occurrence of ascites in broilers (Walton et al., 2001), while in some cases the incidence of ascites was increased by supplementing vitamins $\mathrm{E}$ and $\mathrm{C}$ to these diets.

L-carnitine has received research attention for its antiperoxidative effect and role in increasing broiler heart weight. Tan et al. (2008) examined the effect of supplementation of basal diets with $100 \mathrm{mg} / \mathrm{kg}$ l-carnitine on mortality due to pulmonary hypertension syndrome in broilers of both sexes exposed to cold conditions, and suggested that supplemental l-carnitine may have increased the weight of the left side of the heart and, hence, reduced the incidence of pulmonary hypertension in the early growth stage.

When studying the effect of dietary supplementation with coenzyme $\mathrm{Q}_{10}$ on growth performance and ascites in Arbor Acre male broiler chicks, Geng et al. (2004) found a preventive effect of dietary $\operatorname{CoQ}_{10}$ on ascites induced in young broilers, with the best effects achieved at $40 \mathrm{mg} \mathrm{CoQ}_{10}$ per $\mathrm{kg}$ feed. The authors reported that body weight gain, average feed intake and feed conversion ratio were not significantly affected by $\mathrm{CoQ}_{10}$ supplementation in broilers during 0 to 
21 days, 22 to 42 days, and 0 to 42 days, and that $\mathrm{CoQ}_{10}$ supplementation significantly decreased the ascites heart index (AHI) compared with the control $(\mathrm{P} \leq 0.05)$, with $40 \mathrm{mg} / \mathrm{kg} \mathrm{CoQ}_{10}$ being more effective than $20 \mathrm{mg} / \mathrm{kg}$. It is possible that $\mathrm{CoQ}_{10}$ protects the cell membrane and cell structure against peroxidation, thus enabling cardiac myocytes and erythrocytes to be healthier and more tolerant to the metabolic stress.

Dietary electrolyte balance seems to be another factor in ascites prevention (Issac et al., 2010).

Sodium is the major cation within the extracellular fluid, and plays a role in maintaining balance between basal and acid elements in the blood serum and plasma. Maslić-Strižak et al. (2012) stressed that high sodium concentrations in diets for broiler chickens contribute to pulmonary hypertension syndrome. Therefore, the authors recommended not more than $2000 \mathrm{mg}$ sodium per $\mathrm{kg}$ of feed, and that not only the levels of $\mathrm{Na}$ from supplemental $\mathrm{NaCl}$ but also those from feed ingredients and drinking water should be taken into account when formulating feed for broilers. Specifically, if sodium is present in drinking water, its feed content is reduced by $1000-1500 \mathrm{mg} / \mathrm{kg}$ for every $500 \mathrm{mg} / \mathrm{l}$ of water, and drinking water for broiler chickens should contain less than $1000 \mathrm{mg} / \mathrm{kg}$ sodium. The adverse effect of $\mathrm{Na}$ on ascites is also reported by Mirsalimi et al. (1992), whereas Gupta et al. (2011) gave special importance to the need to avoid excess sodium in broiler feed as sodium increases blood volume, thus causing pulmonary hypertension.

Julian et al. (1992) also studied the effect of dietary sodium on right ventricular failure-induced ascites, weight gain and fat deposition in male Arbor Acres chickens, and found that increasing dietary levels of $\mathrm{Na}^{+}$from $\mathrm{NaCl}$ and $\mathrm{NaHCO}_{3}$ increased ascites-induced mortality and day 3 to 4 body weight gain, and decreased day 42 body weight. No significant differences were observed in day 56 feed conversion or body weight, carcass weight, chilled carcass weight or abdominal fat-pad weight. The authors drew the following conclusions

1. Excess levels of dietary $\mathrm{Na}^{+}$cause pulmonary hypertension in broiler chickens, as determined by an increased ratio of right ventricle to total ventricle, and water $\mathrm{Na}^{+}$exhibits higher toxicity than feed $\mathrm{Na}^{+}$regardless of the additive effects of feed and water $\mathrm{Na}^{+}$.

2. The toxicity threshold concentration of $\mathrm{Na}^{+}$is about $0.12 \%$ in drinking water, and $0.20 \%$ in the feed; $\mathrm{Na}^{+}$toxicity in broiler chickens increases markedly above this threshold.

3. Cool temperatures and dietary $\mathrm{Na}^{+}$are triggers for pulmonary hypertension in broiler chickens.

Ekanayake et al. (2004) evaluated the effect of different concentrations of supplemental sodium from $\mathrm{NaCl}(0.25 \%, 0.75 \%, 1.5 \%$ and $2 \%)$ in Arbor Acres male broilers on pulmonary hypertension-induced ascites and right ventricular failure. Significance was observed between cumulative mortality and incidence of ascites at day $43(\mathrm{P}<0.05)$. Also, there was a significant $(\mathrm{P}<0.001)$ effect of 
treatment on heart weight, right ventricle:total ventricle, heart weight:carcass weight and right ventricle:carcass weight with the increase in the dietary level of sodium.

In their analysis of the effect of age of exposure and dietary acidification or alkalisation on mortality due to broiler pulmonary hypertension syndrome, Owen et al. (1994) concluded that dietary supplementation with $1 \%$ sodium bicarbonate $\left(\mathrm{NaHCO}_{3}\right)$ reduced the incidence of ascites-induced death, in contrast to dietary acidification with ammonium chloride (1\%), which increased the rate of mortality, but with no significance observed. The authors associated this phenomenon with the very nature of these compounds $\left(\mathrm{NaHCO}_{3}\right.$ reduces acidity as it is alkaline, whereas $\mathrm{NH}_{4} \mathrm{Cl}$ reduces alkalinity as it is an acid compound).

Water quality induces ascites only if it contains excess $\mathrm{Na}^{+}$. Ascites can be prevented by reducing water availability (Julian and Squires, 1995).

Adding potassium carbonate to drinking water (1 $\mathrm{mg}$ per litre of water) can reduce the incidence of ascites as this carbonate increases blood oxygen supply. However, broilers receiving potassium carbonate had the lowest body weights at day 42, as opposed to control birds and broilers receiving $\mathrm{NaCl}$ and $\mathrm{NH}_{4} \mathrm{Cl}$ through water (Shlosberg et al., 1998). The same authors found that $10 \%$ feed restriction was also effective in reducing ascites, and that broilers fed feedrestrictive diets and those receiving $3 \mathrm{mg} \mathrm{KHCO}_{3} / \mathrm{l}$ water had similar arterial blood oxygen saturation.

Unlike potassium, sodium ions $\left(\mathrm{Na}^{+}\right)$seem to have high potential to cause ascites. Therefore, the use of $\mathrm{KHCO}_{3}$ has been recommended instead of $\mathrm{NaHCO}_{3}$ (Balnave and Gorman, 1993).

Using feed ingredients rich in n-3 fatty acids (fish meal, fish oil, flaxseed oil, canola oil, etc.) for broiler chickens has proved useful in alleviating pulmonary hypertension syndrome as alpha-linolenic acid, found in these feedstuffs, is involved in the synthesis of some prostacyclins, which function as coronary relaxants (Issac et al. 2010).

\section{Feed form}

Pelleting improves the hygienic safety of feed and reduces dustiness, thus improving air quality in the poultry house. However, pelleted feed has a number of disadvantages. Specifically, due to their better digestibility and intake preference for broiler chickens, pellets are a potential cause of ascites (Silva et al., 1988; Julian, 2000; Issac et al., 2010). Bölükbasi et al. (2005) found that mash feed significantly reduced the incidence of ascites $(\mathrm{P}<0.05)$ compared to pelleted feed. Maslić-Strižak et al. (2012) recommended feeding diets in the mash form for fast-growing hybrids.

Deficiencies lead to severe rickets associated with weak ribs and breathing problems. As a consequence, hypoxic hypoxaemia occurs, inducing polycythaemia and increasing blood viscosity, thus provoking ascites. Under 
phosphorus deficiency, the release of oxygen from haemoglobin may be reduced (Julian, 1993).

High dietary energy levels increase the growth rate of broilers and the incidence of ascites. However, as broilers are fed low-energy diets to a greater extent, they have a higher oxygen requirement for digestion. To reduce oxygen requirement, especially under warm conditions, some carbohydrates should be replaced with vegetable fat (Julian and Squires, 1995).

Complete feeds for broiler chickens should be designed at low energy levels (Gupta et al., 2011), with energy requirements satisfied by fats, rather than by glucose (Maslić-Strižak et al., 2012). Limiting energy consumption through limited feed intake can affect metabolic rate and induce hypoxaemia in fastgrowing hybrids (Acar et al., 1995, Balog, 2003, Sahraei 2014).

Issac et al. (2010) also recommended low-energy diets, particularly in the early feeding period, when feed intake per unit of metabolic weight is the highest. Lipid peroxidation has been suggested to play a role in cardiac tissue degeneration as well as in the development of pulmonary hypertension syndrome.

Currie (1999) found that the oxygen requirement of broilers during the growing period is reduced by feeding a low protein and low energy diet during the first 14 days.

Broilers are subjected to a number of management practices aimed at limiting their growth rate. These practices, including feed restriction, nutrient density and diet form, indirectly reduce oxygen demand to partially counterbalance the physiological limitations; furthermore, research has focused on normalising red blood cell structure and function, and free radical scavenging activity (Baghbanzadeh et Decuypere, 2008). Feed restriction programmes based on a skip-a-day or skip-two-days method used during the early growth period were effective in reducing the incidence of ascites.

\section{Feed restriction}

Given the genetic predisposition of fast-growing broilers to good appetite and eating until exhaustion, feed restriction (either quantitative or qualitative) during the first week of life can decrease the rate of mortality by $75 \%$ (Maslić-Strižak et al., 2012).

Restricted feed consumption and, hence, reduced intake of nutrients can reduce the incidence of ascites in the flock and death of birds (Shlosberg et al., 1991). As there is a direct correlation between metabolic rate and ascites, the incidence of ascites can be reduced by limiting growth rate through feed restriction programmes using mash diets, feeds low in nutrients, and supplemental antioxidants and omega-3 fatty acids (Singh et al., 2011).

Feed restriction resulted in a $7 \%$ reduction in feed consumption, including the intake of microelements essential for proper bone formation, mainly vitamin $\mathrm{D}_{3}$, $\mathrm{Ca}, \mathrm{P}, \mathrm{Zn}$ and $\mathrm{Cu}$. The high incidence of leg disorders in broilers receiving 
restricted feed with no microelement supplementation was due to the deficiency of essential microelements. This result was supported by the findings from the feeding treatment with $5 \%$ of supplemental amino acids, vitamins and minerals. As indicated by the results, quantitative feed restriction, which started at 7 days of age, with microelement supplementation administered to broiler diet, was effective in reducing total mortality, ascites-induced mortality and leg problems in broiler chickens. Moreover, under this feeding programme, the compensatory growth of feed-restricted broilers was sufficient to match the production and carcass properties of control birds at 49 days of age (Camacho et al., 2004).

Arce et al. (1992) found that, under different broiler feeding systems (ad libitum, eight hours per day, $10 \%$ below that of full-fed controls), the incidence of ascites was significantly reduced by both feed restriction methods, while growth rate was slightly increased. Skip-a-day feeding programmes, employed at days $7-13$ or $15-21$ of broiler age, were also efficient in preventing ascites, with no decrease in growth rate and no deterioration of the feed conversion ratio. Maxwell and Robertson (1997) suggested using a skip-a-day programme during the starter stage, beginning from day 7 until day 13 of age, and feeding a lowprotein diet to reduce the incidence of ascites from over $30 \%$ to $5 \%$.

Having analysed broiler sex, highly concentrated energy diets, low energy diets, time-restricted feeding, feeding ad libitum and restricted feeding (90\%), Camacho-Fernandez et al. (2002) recommended the use of restricted feeding (through feeding time restrictions or feed ration restrictions) as the most efficient method in terms of feed efficiency, ascites-induced mortality and carcass yield, and found that $10 \%$ feed restriction achieved the highest profit on a live weight or carcass basis.

Broiler rearing systems involving low growth rates considerably decrease the incidence of ascites (Druyan et Cahaner, 2007). Kalmar (2013) recommended growth restriction either through quantitative feed restriction (by decreasing the daily feed intake or by providing periodic feeding, through day length reductions) or qualitative feed restriction (use of low-energy feeds).

\section{Conclusion}

Ascites is a complex issue continuously occurring in poultry production. Causes of ascites are very difficult to identify. Proper broiler nutrition is a major non-genetic factor responsible for the success of poultry meat production, as well as for the prevention of ascites and the associated damage. Advances in poultry selection must involve appropriate feeding systems, proper feed formulations, use of nutritive and non-nutritive feed additives, etc. Further research should be based on determining a proper rearing and diet management system devoid of any reason for the incidence of the pulmonary hypertension syndrome. 


\section{Acknowledgments}

This study is part of Project No. 31033 titled "Sustainable Conventional and Revitalised Traditional Production of Value-Added Poultry Meat and Eggs" funded by the Ministry of Science and Technological Development of the Republic of Serbia.

\section{References}

Acar N., Sizemore F.G., Leach G.R., Wideman R.F., Owen R.L., Barbato G.F. (1995): Growth of broiler chickens in response to feed restriction regimens to reduce ascites. Poultry Science, 74 (5): 833-843.

Aftab U., Khan A.A. (2005): Strategies to alleviate the incidence of ascites in broilers: a review. Brazilian Journal of Poultry Science, 7 (4): 199-204.

Al-Mesri F., Hassanzadeh M. (2010): Anatomical parameters of cardiopulmonary system, venous blood $\mathrm{pCO}_{2}$ and $\mathrm{pO}_{2}$ tensions and the development of ascites syndrome in two genetic line chickens that are differing in their growth rate. Iranian Journal of Veterinary Research, 11 (3): 214-221.

Akşit M., Özge A., Aslihan Büyüköztürk Karul, Balkaya M., Özdemir D. (2008): Effects of cold temperature and vitamin E supplementation on oxidative stress, Troponin-T level, and other ascites-related traits in broilers. Archiv für Geflügelkunde, 72 (5): 221-230.

Arce J., Berger M., Lopez Coello C. (1992): Control of ascites syndrome by feed restriction techniques. The Journal of Applied Poultry Research, 1 (1): 1-5.

Baghbanzadeh A., Decuypere E. (2008): Ascites syndrome in broilers: physiological and nutritional perspectives. Avian Pathology, 37 (2): 117-126.

Balnave D., Gorman I. (1993): A role for sodium bicarbonate supplements for growing broilers at high temperatures. World's Poultry Science Journal, 49(3): 236-241.

Balog J.M. (2003): Ascites syndrome (pulmonary hypertension syndrome) in broiler chickens: are we seeing the light at the end of the tunnel? Avian and Poultry Biology Reviews, 14 (3): 99-126.

Balog J.M., Kidd B.D., Anthony N.B., Huff G.R., Huff W.E., Rath N.C. (2003): Effect of cold stress on broilers selected for resistance or susceptibility to ascites syndrome. Poultry Science, 82 (9): 1383-1388.

Basmacioğlu Malayoğlu H., Özkan S., Koçtürk S., Oktay G., Ergül M. (2009): Dietary vitamin $\mathrm{E}$ ( $\alpha$-tocopheryl acetate) and organic selenium supplementation: performance and antioxidant status of broilers fed n-3 PUFA-enriched feeds. South African Journal of Animal Science, 39(4): 274-285.

Bautista-Ortega J., Ruiz-Feria C.A. (2010): L-Arginine and antioxidant vitamins E and C improve the cardiovascular performance of broiler chickens grown under chronic hypobaric hypoxia. Poultry Science, 89 (10): 2141-2146.

Bendheim U., Berman E., Zadikov I., Shlosberg A. (1992): The effects of poor ventilation, low temperatures, type of feed and sex of bird on the development of ascites in broilers. Production parameters. Avian Pathology, 21 (3): 383-388.

Bhagat A., Nagi A., Moustafa A. (1990): Pathological studies on furazolidone toxicosis in chicks. Egyptian Journal of Comparative Pathology and Clinical Pathology, 3: 149-158. 
Bölükbasi S.C., Aktas M.S., Güzel M. (2005): The effect of feed regimen on ascites induced by cold temperatures and growth performance in male broilers. International Journal of Poultry Science, 4 (5): 326-329.

Camacho M.A., Suarez M.E., Herrera J.G., Cuca J.M., Garcia-Bojalil C.M. (2004): Effect of age of feed restriction and microelement supplementation to control ascites on production and carcass characteristics of broilers. Poultry Science, 83 (4): 526-532.

Camacho-Fernández D., López C., Ávila E., Arce J. (2002): Evaluation of different dietary treatments to reduce ascites syndrome and their effects on corporal characteristics in broiler chickens. The Journal of Applied Poultry Research, 11 (2): 164-174.

Currie Richard J.W. (1999): Ascites in poultry: Recent investigations. Avian Pathology, 28 (4): 313-326.

Decuypere E., Buyse J., Buys N. (2000): Ascites in broiler chickens: exogenous and endogenous structural and functional causal factors. World's Poultry Science Journal, 56 (4): 367-377.

Decuypere E., Hassanzadeh M., Buys N. (2005): Further insights into the susceptibility of broilers to ascites. The Veterinary Journal, 169 (3): 319-320.

Druyan S. (2012): Ascites syndrome in broiler chickens - a physiological syndrome affected by red blood cells. Moschandreou Teryy E. (ed) book, Blood cell - an overview of studies in hematology chapter 13, 243-270 (Verlag Eugen Ulmer, Stuttgart).

Druyan S., Cahaner A. (2007): Segregation among test-cross progeny suggests that two complementary dominant genes explain the difference between ascites-resistant and ascites-susceptible broiler lines. Poultry Science, 86 (11): 2295-2300.

Ekanayake S., Silva S.S.P., Priyankarage N., Asekara M.J., Horadagoda N., Abeynayake P., Gunaratne S.P. (2004): The effect of increased sodium in feed on pulmonary hypertension-induced ascites and right ventricular failure in broiler chickens. Spring meeting of the WPSA uk branch, Vol. 45 (supplement 1): 29-30.

Franciosini M.P., Tacconi G., Leonardi L. (2012): Ascites syndrome in broiler chickens. Veterinary Science Research, 3 (1): 60-66.

Geng A.L., Guo Y.M., Yang Y. (2004): Reduction of ascites mortality in broilers by coenzyme Q10. Poultry Science, 83 (9): 1587-1593

Groves P. (1997): Broiler ascites syndrome: a review. Proceedings Australian Poultry Science Symposium, 85-91.

Gupta A.R. (2011): Ascites syndrome in poultry: a review. World's Poultry Science Journal, 67 (3): 457-467.

Hassanzadeh M., Bozorgmehri Fard M.H., Buys J., Decuypere E. (2003): Beneficial effects of alternative lighting schedule on the incidence of ascites and on metabolic parameters of broiler chickens. Acta Veterinaria Hungaria, 51 (4): 513-520.

Iqbal M., Cawthon D., Beers K., Wideman R.F., Bottje W.G. (2002): Antioxidant enzyme activities and mitochondrial fatty acids in pulmonary hypertension syndrome (PHS) in broilers. Poultry Science, 81 (2): 252-260.

Issac Yancy Mary, Abraham John, Sreeparvathy George Jini, Balusami C. (2010): Managemental practices to control ascites in a flock. Veterinary World, 3 (5): 250-252.

Julian R.J., Friars G.W., French H., Quinton M. (1986): The relationship of right ventricular hypertrophy, right ventricular failure, and ascites to weight gain in broiler and roaster chickens. Avian Diseases, 31: 130-135. 
Julian R.J., Boulianne M. (1988): Natural and experimental lung pathology causing pulmonary hypertension, right ventricular hypertrophy, right ventricular failure and ascites in broiler chickens. American Journal of Veterinary Research, 192: 1781(abstr. 209).

Julian R.J., Caston J.Linda, Leeson S. (1992): The effect of dietary sodium on right ventricular failure-induced ascites, gain and fat deposition in meat-type chickens. Canadian Journal of Veterinary Research, 56 (3): 214-219.

Julian R.J., Mirsalimi S.M. (1992): Blood oxygen concentration of fast-growing and slowgrowing broiler chickens with ascites from right ventricular failure. Avian Diseases, 36: 730-732.

Julian R.J. (1993): Ascites in poultry. Avian Pathology, 22 (3): 419-454.

Julian R.J., Squires E.J. (1995): Suggestions for reducing ascites in meat-type chickens. Proceedings of the 44th Western Poultry Diseases Conference, Sacramento, CA, USA, 19-20.

Julian R.J. (1998): Rapid growth problems: ascites and skeletal deformities in broilers. Poultry Science, 77 (12): 1773-1780.

Julian R.J. (2000): Physiological, management and environmental triggers of the ascites syndrome: a review. Avian Pathology, 29 (6): 519-527.

Kalmar I.D., Vanrompay D., Janssens G.P.J. (2013): Broiler ascites syndrome: collateral damage from efficient feed to meat conversion. The Veterinary Journal, 197 (2): 169174.

Ladmakhi H.M., Buys N., Dewil E., Rahimi G., Decuypere E. (1997): The prophylactic effect of vitamin $\mathrm{C}$ supplementation on broiler ascites incidence and plasma thyroid hormone concentration. Avian Pathology, 26 (1): 33-44.

Lin Yih-Fwu, Tsai Hsiu-Ling, Lee Yi-Chun, Chang Sue-Joan (2005): Maternal vitamin E supplementation affects the antioxidant capability and oxidative status of hatching chicks. The Journal of Nutrition, 135 (10): 2457-2461.

Lorenzoni A.G., Ruiz-Feria C.A. (2006): Effects of vitamin E and L-arginine on cardiopulmonary function and ascites parameters in broiler chickens reared under subnormal temperatures. Poultry Science, 85 (12): 2241-2250.

Martrenchar A., Morisse J.P., Huonnic D., Cotte J.P. (1997): Influence of stocking density on some behavioural, physiological and productivity traits of broilers. Veterinary Research, 28: 473-480.

Maslić-Strižak D., Spalević LJ., Rašeta M., Branković-Lazić I. (2012): Uzgoj brojlerskih pilića u industrijskom živinarstvu. Tehnologija mesa, 53 (1): 1-7.

Maxwell M.H., Robertson G.W. (1997): World broiler ascites survey. Poultry International, 36: 1630.

McGovern R.H., Feddes J.J.R., Robinson F.E., Hanson J.A. (2000): Growth, carcass characteristics, and incidence of ascites in broilers exposed to environmental fluctuations and oiled litter. Poultry Science, 79 (3): 324-330.

Mirsalimi S.M., O’brien P.J., Julian R.J. (1992): Changes in erythrocyte deformability in $\mathrm{NaCl}$-induced right-sided cardiac failure in broiler chickens. American Journal of Veterinary Research, 53: 2359-2363.

Owen R.L., Wideman R.F., Leach R.M., Cowen B.S., Dunn P.A., Ford B.C. (1994): Effect of age of exposure and dietary acidification or alkalization on mortality due to broiler pulmonary hypertension syndrome. The Journal of Applied Poultry Research, 3 (3): 244-252. 
Ruiz-Feria C.A. (2009): Concurrent supplementation of arginine, vitamin E, and vitamin $\mathrm{C}$ improve cardiopulmonary performance in broilers chickens. Poultry Science, 88 (3): $526-535$.

Sahraei M. (2014): Effects of feed restriction on metabolic disorders in broiler chickens: a review. Biotechnology in Animal Husbandry, 30 (1): 1-13.

Scheele C.W., Van Der Klis J.D., Kwakernaak C., Dekker R.A., Van Middelkoop J.H., Buyse J., Decuypere E. (2005): Ascites and venous carbon dioxide tension in juvenile chickens of highly selected genotypes and native strains. World's Poultry Science Journal, 61 (1): 113-129.

Shlosberg A., Berman E., Bendheim U., Plavnik I. (1991): Controlled early feed restriction as a potential means of reducing the incidence of ascites in broilers. Avian Diseases, 35: 681-684.

Shlosberg A., Bellaiche M., Berman E., Ben David A., Deeb N., Cahaner A. (1998): Comparative effects of added sodium chloride, ammonium chloride, or potassium bicarbonate in drinking water of broilers, and feed restriction, on the development of the ascites syndrome. Poultry Science, 77 (9): 1287-1296.

Silva J.M.L., Dale N., Luchesi J.B. (1988): Effect of pelleted feed on the incidence of ascites in broilers reared at low altitudes. Avian Diseases, 32: 376-378.

Singh P.K., Shekhar Pallav, Kumar Kaushal (2011): Nutritional and managemental control of ascites syndrome in poultry. International Journal of Livestock Production, 2 (8): 117-123.

Surai P.F. (2000): Effect of selenium and vitamin E content of the maternal diet on the antioxidant system of the yolk and the developing chick. British Poultry Science, 41 (2): 235-243.

Tan X., Hu S.H., Wang X.L. (2008): The effect of dietary 1-carnitine supplementation on pulmonary hypertension syndrome mortality in broilers exposed to low temperatures. Journal of Animal Physiology and Animal Nutrition, 92 (2): 203-210.

Villar-Patino G., Diaz-Cruz A., Avila-Gonzalez E., Guinzberg R., Pablos J.L., Pina E. (2002): Effects of dietary supplementation with vitamin $\mathrm{C}$ or vitamin $\mathrm{E}$ on cardiac lipid peroxidation and growth performance in broilers at risk of developing ascites syndrome. American Journal of Veterinary Research, 63(5): 673-676.

Walton J.P., Julian R.J., Squires E.J. (2001): The effect of dietary flax oil and antioxidant on ascites and pulmonary hypertension in broilers using a low temperature model. British Poultry Science, 42 (1): 123-129.

Xiang R.P., Sun W.D., Wang J.Y., Wang X.L. (2002). Effect of vitamin C on pulmonary hypertension and muscularization of pulmonary arterioles in broiler. British Poultry Science, 43 (5): 705-712.

Xun Tan, Jia-Qiang Pan, Jin-Chun Li, Yan-Juan Liu, Wei-Dong Sun, Xiao-Long Wang (2005): L-Arginine inhibiting pulmonary vascular remodelling is associated with

promotion of apoptosis in pulmonary arterioles smooth muscle cells in broilers. Research in Veterinary Science, 79 (3): 203-209. 
Acta Agriculturae Serbica, Vol. XXIV, 48(2019); 119-133

\title{
NUTRITIVNI ASPEKTI POJAVE ASCITESA KOD ŽIVINE
}

\author{
Vladimir Dosković ${ }^{1}$, Snežana Bogosavljević-Bošković1, Zdenka Škrbić ${ }^{2}$ \\ Miloš Lukić2 , Božidar Milošević ${ }^{3}$, Simeon Rakonjac ${ }^{1}$, Veselin Petričević ${ }^{2}$ \\ ${ }^{1}$ Univerzitet u Kragujevcu, Agronomski fakultet u Čačku, Srbija \\ ${ }^{2}$ Institut za stočarstvo, Beograd-Zemun, Srbija \\ ${ }^{3}$ Univerzitet u Prštini, Poljoprivredni fakultet Kosovska Mitrovica-Zubin Potok- \\ Lešak, Srbija
}

\begin{abstract}
Rezime
Sindrom plućne hipertenzije ili ascites predstavlja složen i kompleksan problem u živinarskoj proizvodnji. Na pojavu ovog oboljenja utiču brojni faktori, kako genetski (genotip, pol), tako i paragenetski faktori (nadmorska visina, neadekvatan proces inkubacije jaja, ambijentalni uslovi u živinarniku, ishrana...). Rezultati brojnih istraživanja pokazuju da je neadekvatna ishrana pilića, kao i interakcija ishrane i ostalih faktora, jedan od glavnih razloga zbog kojih se javljaju simptomi ascitesa. Zbog toga, posebnu pažnju treba obratiti na sadržaj antioksidativnih sastojaka, nekih mineralnih materija, energije i proteina u hrani, formu hrane i način ishrane, kao i na obogaćivanje smeša za piliće nekim sastojcima koji ublažavaju pojavu ascitesa.
\end{abstract}

Ključne reči: živina, ascites sindrom, ishrana. 